Omni-Akuatika, 15 (1): 59-65, 2019
ISSN: 1858-3873 print / 2476-9347 online
Research Article
journal homepage: http://ojs.omniakuatika.net

\title{
Milkfish (Chanos chanos Forskal) Traditional Pond Stability Based on Microalgae Periphyton Availability and Water Quality Analyses
}

\author{
Sulastri Arsad ${ }^{1}$, Luthfiana Aprilianita Sari ${ }^{2}$, Muhammad Zainuddin ${ }^{3}$, Muhammad Musa ${ }^{* 1}$ \\ ${ }^{1}$ Faculty of Fisheries and Marine Science, Universitas Brawijaya, Jl. Veteran Malang 65145, Indonesia \\ ${ }^{2}$ Faculty of Fisheries and Marine Science, Universitas Airlangga, Kampus C Mulyorejo Surabaya 60115, \\ Indonesia \\ ${ }^{3}$ Faculty of Science and Technology, Universitas Islam Nahdlatul Ulama Jepara 59427, Indonesia
}

*Corresponding author:musa_fpi@ub.ac.id

Received 9 July 2018; Accepted 19 April 2019; Available online 31 May 2019

\begin{abstract}
Milkfish (Chanos chanos) is one of the highly commercial fisheries commodities in Indonesia. Pond stability of milkfish especially in the juvenile phase can be influenced by several factors including periphyton availability and water quality. This recent study aimed to assess the milkfish traditional pond stability in the fingerling phase based on microalgae periphyton availability and water quality aspects. The research was conducted in a traditional pond located in UPT Fisheries Brackish and Saline Water Probolinggo for three months. Microalgae periphyton and water quality analyses were conducted in situ and ex situ, respectively. The results show that Microalgae periphyton was from sub division Bacillariophyceae and Chlorophyceae were found during the research. However, the abundance of Bacillariophyceae is significantly higher than another descriptively. Furthermore, several parameters of water quality are in good condition (stable) except for ammonia, TOM, and orthophosphate. PCA analyses depicts the relation between microalgae periphyton and water quality which transparency, DO, TOM, temperature, and ammonia were the more influenced factors to the abundance of microalgae periphyton in pond.
\end{abstract}

Keywords: fingerling, milkfish, periphyton, traditional pond

\section{Introduction}

Milkfish are widely cultured in Indonesia which belongs to big ten commodities with high production (KKP, 2015; Suharno et al, 2017). They are hardy and one of the cheapest sources of protein, which are economically acceptable to the consumer within the country (Baliao et al., 1999; WWF, 2014). These species are more stable on their growth than shrimp. Besides, the culture process is less complicated because most of the culture system is held traditionally. Characterization of traditional culture system is low species density in a pond and no water quality control during the culture period (Prasetio et al, 2010; Arsad et al, 2017). In general, milkfish culture consists of several phases: hatchery, fingerling and rearing phase at the end. Naturally, these organisms consume natural feed such as plankton and periphyton in pond depend on their size and age. Natural feed types availability influenced by environment water quality. Diatoms would be abundant when the water quality in the pond is good enough. However, Cyanophyta would be dominant when the water quality is on poor condition.

The aim of the present study was to assess the milkfish traditional pond stability in the fingerling phase based on microalgae periphyton availability and water quality aspects. These aspects are very important during milkfish growth and their production as well as their food habit.

\section{Materials and Method}

The research was carried out in milkfish fingerling traditional pond during three months in UPT Fisheries Brackish and Saline Water Probolinggo (Fig 1). Both microalgae periphyton and water quality samples were collected for three times with 
two sites (inlet and outlet) every two weeks during the research. Several water quality measurements were conducted in situ i.e temperature $\left({ }^{\circ} \mathrm{C}\right.$, DO meter 5510), transparency $(\mathrm{cm}$, Secchi disk), salinity (\%o, Refractometer HTC), dissolved oxygen (mg $\mathrm{L}^{-1}$, DO meter 5510), $\mathrm{pH}$ ( $\mathrm{pH}$ meter Hanna), and $\mathrm{CO}_{2}$ ( $\mathrm{mg} \mathrm{L} \mathrm{L}^{-1}$, Titration technique). Furthermore, Nitrate (mg $\mathrm{L}^{-1}$ ), Orthophosphate $\left(\mathrm{mg} \mathrm{L}^{-1}\right)$, Total Organic Matter (TOM, $\mathrm{mg} \mathrm{L}^{-1}$ ), Ammonia $\left(\mathrm{mg} \mathrm{L}^{-1}\right)$, microalgae periphyton identification, composition, and abundance (Ind $\mathrm{cm}^{2}$ ) were measured ex situ.

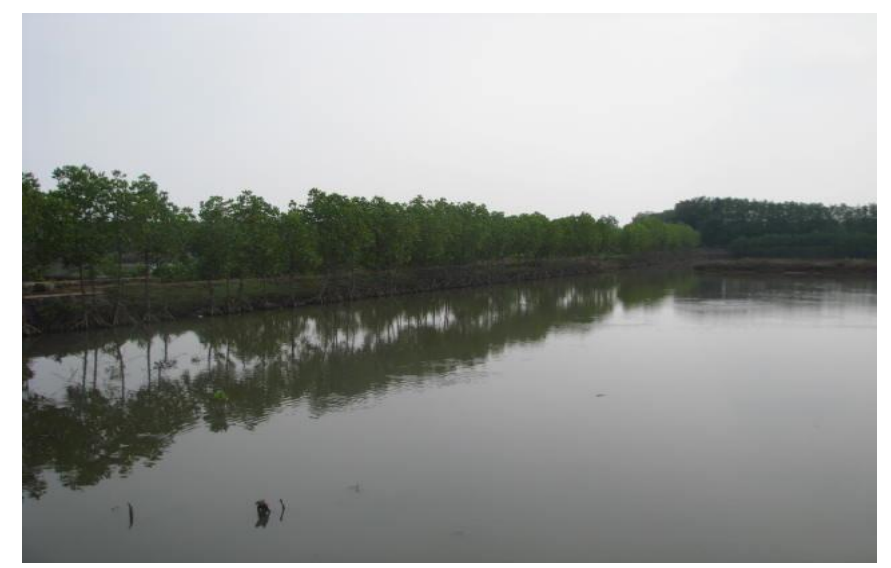

Fig 1. Fingerling Traditional Pond of Milkfish (Research documentation, 2017)

\subsection{Microalgae Periphyton Sampling and Analyses}

In the beginning, the artificial substrate (ceramic $20 \times 20 \mathrm{~cm}^{2}$ ) was placed in the bottom of the pond and leaved it for 14 days. Furthermore, the artificial substrate was taken to the surface to remove the periphyton which attached in the substrate by using smooth teeth-brush into the pail while rinsing the ceramic with water (Weitzel (1979), Biggs and Kilro (2000) modified, personal comm. Arfiati, 2017). This process was done each two weeks for three times. Moreover, the water containing periphyton is pulled into the bottle film and preserved by adding lugol and transported to the laboratory for further analyses.

Microalgae periphyton types were identified by manual book identification of Prescot (1978) and Davis (1955). Microalgae periphyton abundance then determined by using APHA (2005) by the following equation:

$$
\mathrm{K}=\frac{\mathrm{n} \cdot \text { At. Vt }}{\text { Ac. Vs. As }}
$$

Where $K$ is the periphyton abundance (Ind $\mathrm{cm}^{-2}$ ), $n$ is the number of periphyton observed (Ind), As is substrates wide (20x20 $\left.\mathrm{cm}^{2}\right)$, At is cover glass wide $\left(20 \times 20 \mathrm{~mm}^{2}\right)$,
$A c$ is width field of view $\left(\mathrm{mm}^{2}\right), V t$ is sample volume of periphyton $(\mathrm{mL})$, and $V s$ is the sample volume observed $(\mathrm{mL})$.

Relative abundance (\%) was also measured to see the presentation of each division found during the study in the following equation (Prescott, 1970):

$K R=\frac{n i}{N} x 100 \%$

Where $K R$ is relative abundance (\%), ni is the individual number in the genus (Ind), and $N$ is the total of individual observed.

Diversity index was calculated to categorize the pond stability based on periphyton abundance by using Shanon Wiever (1949) formula (Sournia, 1978):

$\mathrm{H}^{\prime}=\mathrm{Pi} \log 2 \mathrm{pi}$

Where $H^{\prime}$ is the diversity index, $P i$ is $\mathrm{ni} / \mathrm{n}$, and $\log _{2} p i$ is the determined value by Shanon Wiever Table category.

\subsection{Water Quality Indices}

Nitrate and orthophosphate were analyzed by using Spectrophotometry principle (BSN, 2011 and Boyd, 1982), correspondingly. In addition, Total Organic Matter (TOM) was analyzed using Permanganate method (BSN, 2004) and 
Ammonia $\left(\mathrm{NH}_{3}\right)$ was quantified by using Boyd (1982).

\subsection{Statistical Analyses}

All the data were analyzed statistically by using Ms. Excel. 2016 and Minitab 18. According to Sawono (2017), PCA analysis is used to reduce existing variables to fewer principal variables and detect the relationships between variables based on similarity characteristics. PCA analysis could show the more significant variable of ten water qualities which influence the presence of microalgae periphyton.

\section{Results and Discussion}

3.1. Microalgae periphyton Composition and Abundance

Identification result of composition and abundance measurement of microalgae periphyton in fingerling milkfish traditional pond for 6 weeks resulting microalgae periphyton composition i.e Bacillaryophyceae (10 genus) and Chlorophyceae (3 genus). From Bacillaryophyceae, the genus identified consisted of Navicula, Nitzchia, Coconeis, Cymbela, Cyclotella, Pinnularia, Amphora, and Surirella. Therefore, Chlamydomonas, Schroederia, and Ulothrix were identified from Chlorophyceae. Total microalgae periphyton abundance was found in first week of observation was $7,352,090,615$ Ind $\mathrm{cm}^{-2}$, meanwhile for week-2 and week-3 the abundance was 5,652,359,679 and $7,724,221,056$ Ind $\mathrm{cm}^{-2}$, sequentially. Most of the microalgae periphyton found was from sub division Bacillariophyceae. Junda et al (2013), mentioning that microalgae periphyton organisms tend to live in the water area which there is enough of light radiance. The relative abundance (KR) composition of autotroph periphyton illustrates in Fig. 2.

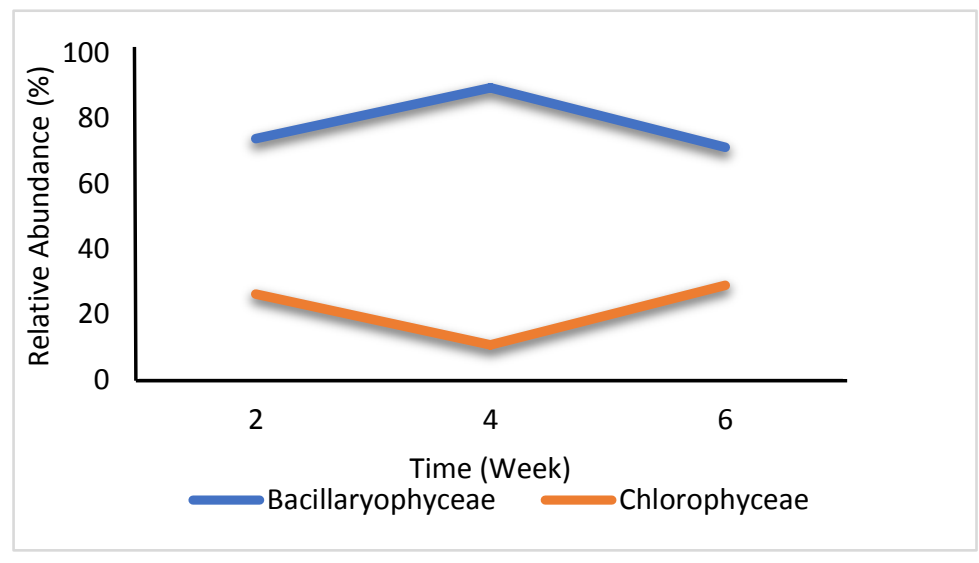

Fig. 2. Relative abundance (\%) of microalgae periphyton in pond

Based on Fig 2., the relative abundance of Bacillariophyceae was more than $70 \%$, whereas Chlorophyceae was only under $30 \%$. It could be explained by their characteristic. Bacillariophyceae is tending to attach to the substrates because they have mucilage short or long gelatin with hard semi round shape. It's also belonged to microalgae, which adapt easily to the environment and they are distributed widely in the aquatic environment (Werner, 1977). This sub division plays an important role as phytoplankton or periphyton because of their function as a food source for zooplankton or herbivore fishes (Reynold, 1990). This is one of the reasons why Bacillariophyceae is very abundant in the water environment.

Diversity index in pond ranged from 2.631 to 3.015 . It indicates that he community of microalgae periphyton belongs to moderate to stable condition. If $H^{\prime}<1$ illustrate that the community is not stable, while $\mathrm{H}^{\prime}$ is between 1-3 is moderate, and $H^{\prime}>3$ assumes that the community is stable. Low diversity index represents that there is a dominance of such species in the water pond, whereas high diversity index shows 
that the water environment is appropriate with algal growth.

\subsection{Water Quality Parameters}

Water quality parameters were measured in inlet and outlet that considerably representatives for describing all the water quality in the pond (Table. 1). Minimum, Maximum, STDEV, and Variation Coefficient (CV) are presented in Table 2. Based on CV value, several water quality parameters i.e. temperature, transparency, $\mathrm{pH}, \mathrm{DO}$, and nitrate were relative stable during 6 weeks of measurement and $\mathrm{CO}_{2}$ value was undetectable (zero). In contrast, TOM, ammonia, and orthophosphate were varied during the research. Patel and Shiyan (2001) stated that the critical limit of CV based on most of the field experience in different spatial and temporal is $33 \%$.

The TOM ranged between 139.04 and $379.20 \mathrm{mg} \mathrm{L}^{-1}$, which is noticeably high. Afu (2005) expressed that normal TOM's value is approximately $0.01-30 \mathrm{mg} \mathrm{L}^{-1}$, and when the value higher than the range means that water environment is polluted by organic matter. Variation in TOM tends to increase from Week 2 to Week 4 then finally decrease in Week 6.

Table 1. Water quality result in pond.

\begin{tabular}{clccc}
\hline No. & \multicolumn{1}{c}{ Parameter } & \multicolumn{3}{c}{ Observation period } \\
\cline { 3 - 5 } & & Week 2 & Week 4 & Week 6 \\
\hline 1 & Temperature $\left({ }^{0} \mathrm{C}\right)$ & 28.10 & 32.80 & 33.00 \\
2 & Transparency $(\mathrm{Cm})$ & 44.35 & 31.85 & 43.25 \\
3 & $\mathrm{pH}$ & 7.80 & 8.20 & 8.10 \\
4 & $\mathrm{DO}\left(\mathrm{mg} \mathrm{L}^{-1}\right)$ & 5.66 & 8.62 & 5.57 \\
5 & $\mathrm{CO}_{2}\left(\mathrm{mg} \mathrm{L}^{-1}\right)$ & 0.00 & 0.00 & 0.00 \\
6 & TOM $\left(\mathrm{mg} \mathrm{L}^{-1}\right)$ & 145.36 & 331.8 & 202.24 \\
7 & Ammonia $\left(\mathrm{mg} \mathrm{L}^{-1}\right)$ & 0.07 & 0.08 & 0.27 \\
8 & Salinity $(\% \circ)$ & 21.00 & 15.50 & 27.00 \\
9 & Nitrate $(\mathrm{ppm})$ & 0.11 & 0.14 & 0.13 \\
10 & Orthophosphate $\left(\mathrm{mg} \mathrm{L}^{-1}\right)$ & 0.04 & 0.07 & 0.004 \\
\hline
\end{tabular}

Table 2. Detail of Water Quality Value in pond

\begin{tabular}{lrrrr}
\hline \multicolumn{1}{r}{ Water Quality indices } & Min & Max & STDEV & CV \\
\hline Temp $\left({ }^{\circ} \mathrm{C}\right)$ & 28.00 & 33.10 & 2.63 & 8.50 \\
Transp $(\mathrm{Cm})$ & 31.30 & 44.50 & 6.20 & 15.58 \\
$\mathrm{pH}$ & 7.80 & 8.20 & 0.19 & 2.32 \\
$\mathrm{DO}(\mathrm{ppm})$ & 5.32 & 8.68 & 1.57 & 23.69 \\
$\mathrm{CO}(\mathrm{ppm})$ & 0.00 & 0.00 & 0.00 & 0.00 \\
$\mathrm{TOM}(\mathrm{ppm})$ & 139.04 & 379.20 & 92.06 & 40.65 \\
Ammonia $(\mathrm{ppm})$ & 0.02 & 0.33 & 0.11 & 81.41 \\
Sal $\left({ }^{0} / 00\right.$ & 15.00 & 27.00 & 5.15 & 24.35 \\
Nitrate $(\mathrm{ppm})$ & 0.08 & 0.16 & 0.03 & 25.41 \\
Orthophosphate $(\mathrm{ppm})$ & 0.004 & 0.07 & 0.026 & 82.84 \\
\hline
\end{tabular}


The fluctuated value of ammonia and orthophosphate (Table. 2) indicates that organic decomposition is not going well as it supposed to be. This could provoke the presence of toxic compounds such as ammonia and high abundance of orthophosphate.

Ammonia value ranged from 0.02 to $0.33 \mathrm{mg} \mathrm{L}^{-1}$. Based on PP RI No. 82 (2001), quality standard ammonia compound is 0.5 $\mathrm{mg} \mathrm{L}^{-1}$. In addition, Lind (1979) estimated that ammonia in the unpolluted water and well-oxidized normally less than $1 \mathrm{mg} \mathrm{L}^{-1}$. This indicates that concentration of ammonia observed in milkfish pond is still under the minimum quality standard. On the other side, orthophosphate is the limiting factor of algal growth. A high value of orthophosphate will cause blooming phenomenon. An optimal value of orthophosphate in water pond ranged from 0.051 to $0.1 \mathrm{mg} \mathrm{L}^{-1}$ (Kadim and Arsad, 2016). In our study, the orthophosphate value in the pond was categorized as low (0.004-0.07 $\left.\mathrm{mg} \mathrm{L}^{-1}\right)$. However, less orthophosphate in pond could be caused by organic decomposition process is not going well.

Table 3. Loading of experimental water quality variables on significant principal components

\begin{tabular}{|c|c|c|}
\hline \multicolumn{3}{|c|}{ Eigenvalue } \\
\hline & F1 & F2 \\
\hline Value & 6.6866 & 3.3134 \\
\hline Proportion & 0.669 & 0.331 \\
\hline \multicolumn{3}{|c|}{ Eigenvectors } \\
\hline Periphyton Abundance & -0.376 & 0.127 \\
\hline Temperature & 0.197 & 0.473 \\
\hline Transparency & -0.387 & -0.009 \\
\hline $\mathrm{pH}$ & 0.285 & 0.371 \\
\hline DO & 0.385 & -0.049 \\
\hline TOM & 0.376 & 0.130 \\
\hline Ammonia & -0.162 & 0.499 \\
\hline Salinity & -0.316 & 0.316 \\
\hline Nitrate & 0.308 & 0.332 \\
\hline Orthophosphate & 0.280 & -0.379 \\
\hline
\end{tabular}

Based on PCA analysis (Table.3), the main factors influencing microalgae periphyton abundance is transparency, Dissolved oxygen (DO), and Total organic matter (TOM) with $\mathrm{F} 1$ value is $66.9 \%$. Meanwhile F2 is $33.1 \%$ showed the main water quality parameter is temperature and ammonia. Therefore, the water quality which influence the abundance of microalgae periphyton was transparency, DO, TOM, temperature, and ammonia. Determination of water quality is determined by looking at the value of the eigenvector which is considered as the largest. 


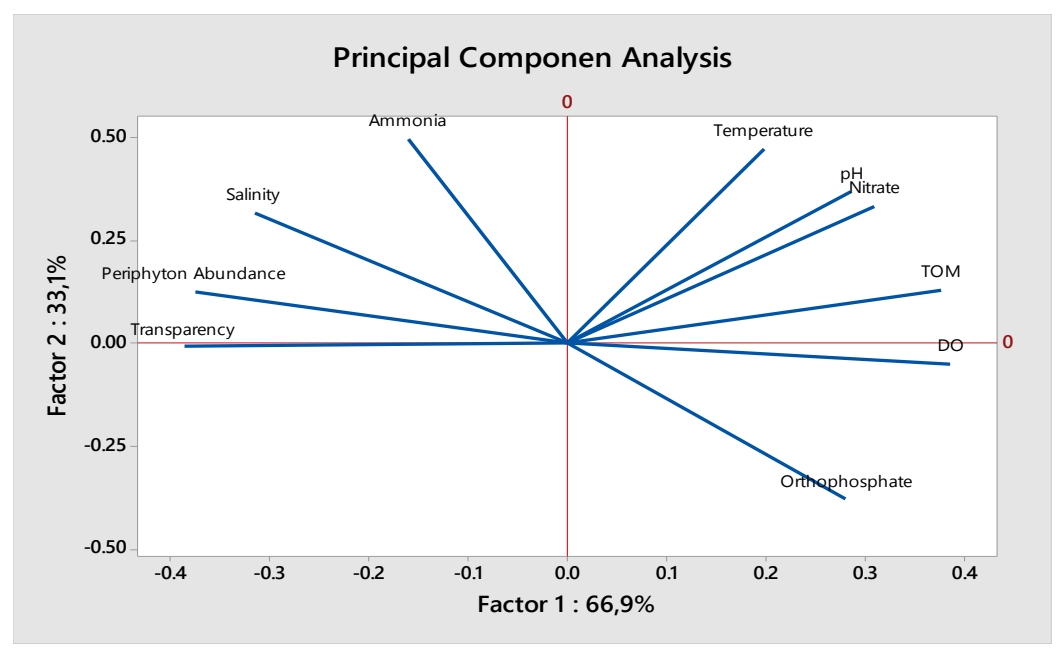

Fig. 3. Principal Component Analyses Between Periphyton Abundance and Water Quality Parameters

Fig. 3 depicts the more influenced water quality is transparency, DO, TOM, temperature and ammonia. The relationship between parameters could also be seen based on the size of the angle, where the presence of periphyton is very closely related to the salinity, transparency, and ammonia. Low transparency value will limit the penetration of light and as consequence of a decrease of photosynthetic ability (Harmoko and Krisnawati, 2018). On the other side, Hutchinson (1967) stated that chlorophyta and diatom preferred nitrogen form of nitrate and ammonia. In addition, salinity is an important environmental factor influencing microalgal growth in marine algal cultures. Changes in cellular volume and osmotic modification were noticed in microalgae within salinity variation (Kumar \& Saramma, 2018). Microalgae is categorized into group of halophilic (salt requiring for optimum growth) and halotolerant (having response mechanism that permits their existence in the saline medium). In both these conditions, microalgae produce some metabolites to protect themselves from salt injury and as a balance to the surrounding osmotic pressure.

\section{Conclusion}

The stability of milkfish pond in terms of biological aspects (microalgae periphyton) was included into category of moderate to stable stability. It means that the research ponds are still quite good and still suitable for cultivation. Furthermore, our study indicates that microalgae periphyton abundance was mostly influenced by transparency, DO, TOM, temperature and ammonia. Therefore, high organic matter is needed to be controlled because it will affect the life of the organism and could cause toxic compounds when the decomposition process is not going well.

\section{Acknowledgments}

This research was financially supported by Dana PNBP Faculty of Fisheries and Marine Science Universitas Brawijaya T.A 2018.

\section{References}

Afu, L. O. Alirman. 2005. The Influence of Organic Matter to Water Quality Parameter in Kendari Bay Sulawesi Tenggara. Bogor Agriculture Institute.

American Public Health Association (APHA). 2005. Standard Method for The Examination of Water and Wastewater. $16^{\text {th }}$ Edition, Washington DC., 1202 p.

Arsad, S., Afandy, A. Purwadhi, A., Maya, B., Saputra, D., Buwono, N.R. 2017. Study of Vaname Shrimp Culture (Litopenaeus vannamei) in Different Rearing System. Journal IImiah Perikanan dan Kelautan Univesritas Airlangga. Vol 9(1), 1-14.

Badan Standarisasi Nasional. 2004. Cara Uji Nilai Permanganat Secara Titrimetri. SNI 06-6989.22. SNI. Jakarta. 10 p. 
Badan Standarisasi Nasional. 2011. Cara Uji Nitrat dengan Spektrofotometer UVVisibel Secara Reduksi Kadmium. SNI 6989.79. SNI. Jakarta. 18 p.

Baliao, D. D., de los Santos, M. A., \& Franco, N. M. 1999. The modular method: Milkfish pond culture. Tigbauan, Iloilo, Philippines: Aquaculture Department, Southeast Asian Fisheries Development Center.

Biggs, B.J., Kilroy, J. 2000. Stream Periphyton Monitoring Manual. NIWA, New Zealand.

Boyd, C.E. 1982. Water Quality Management for Pond Fish Culture. Elsevier, New York, $318 \mathrm{p}$.

Davis, G.C. 1955. The marine and freshwater plankton. Michigan state university press, USA. 526 pages.

Harmoko, Krisnawati, Y. 2018. Mikroalga Divisi Bacillariophyta Yang Ditemukan Di Danau Awur Kabupaten Musi Rawas. Jurnal Biologi, 6(1), 30-35.

Hutchinson, G.E. 1967. Introduction to Lake Biology and The Limnoplankton. John Wiley and Sons. New York.

Junda, M., Hijriah, Y. Hala. 2013. Identification of Periphyton As Water Quality Indicator in Nile Pond (Oreochromus niloticus). Jurnal Kajian, Penelitian, dan Pengajaran Biologi. 14(1) :16-24.

Kadim, M.K., Arsad, S. 2016. Distribution and Abundance of Microalgae Based on Coastal Characteristic and Ecology in Bone Bolango Coastal Region. Asian Jr. of Microbiol. Biotech. Env. Sc. 18(2), 395-401.

KKP-Indonesia. 2015. Ministry of Marine Affairs and Fisheries Indonesia. Basic Data Analyses of Marine and Fisheries 2015. Central Data, Statistic, and Information. $170 \mathrm{p}$.

Kumar, S. and Saramma, A.V. 2018. Effect of Salinity and $\mathrm{pH}$ Ranges on the Growth and Biochemical Composition of Marine Microalgae Nannochloropsis salina. International Journal of Agriculture, Environment, and Biotechnology, 11(4), 651-660.

Lind, O.T. 1979. Handbook of Common Methods in Limnology. $2^{\text {nd }}$ ed. Mosby Company London. $199 \mathrm{p}$.
Patel, N. M. dan R. L. Shiyan. 2001 Coefficient of variation in field experiments and yardstick thereof An empirical study. Current Science, 81(9): 385.

PP RI No. 82 Tahun 2001. Tentang pengelolaan kualitas air dan pengendalian pencemaran air. Deputi Sekretaris Kabinet Bidang Hukum dan Perundang-undangan. $28 \mathrm{p}$.

Prasetio, A.B., Albasri, H., Rasidi. 2010. Milkfish Culture Development in North Coast of Central Java (Case study: Kendal, Pati, Pekalongan). Proceeding Forum Inovation Technology of Aquaculture). Research Centre of Fisheries Culture. Jakarta.

Prescott GW. 1970. The Fresh Water Algae, University of Montana. IOWA.

Reynolds CS. 1990. The Ecology of Freshwater Phytoplankton. Cambridge University Press: London.

Sawono, J. 2017. Mengenal ProsedurProsedur Populer dalam SPSS 23. Jakarta: PT Elex Media Komputindo.

Sournia, A. 1978. Phytoplankton Manual. Publisher: United Nations Educational, Scientific and Cultural Organization. Paris. ISBN: 92-3101572-9.

Suharno, Susilowati, I., Firmansyah. 2017. Management of The Traditional Milkfish Culture in Indonesia: An Approach Using Technical Efficiency of The Stochastic Frontier Production. AACL Bioflux 10(3), 578-586.

Weitzel, R. L., Sanocki, S. L., and Holecek, H. 1979. Sample Replication of Periphyton Collected from Artificial Substrates, Methods and Measurement of Peryphyton Communities: A Review, ASTM STP 690, R. L Weitzel, Ed., American Society for Testing and Materials. Pp. 90-115.

Werner, D. 1977. The Biology of Diatoms. Blackwell Scientific Publications. Vol.13. 498 pages.

WWF-Indonesia. 2014. Better Management Practices: Culture of Milkfish in the environmentally friendly pond. WWFIndonesia. 22 pp. 